\title{
Polo-like Kinase 1 Inhibitor MK1496
}

National Cancer Institute

\section{Source}

National Cancer Institute. Polo-like Kinase 1 Inhibitor MK1496. NCI Thesaurus. Code C82389.

An orally bioavailable Polo-like kinase 1 (Plk1) inhibitor with potential antineoplastic activity. Polo-like kinase 1 inhibitor MK1496 selectively inhibits Plk1, inducing selective G2/M arrest followed by apoptosis in a variety of tumor cells while causing reversible cell arrest at the G1 and G2 stage without apoptosis in normal cells. Plk1, named after the polo gene of Drosophila melanogaster, is a serine/threonine protein kinase involved in regulating mitotic spindle function in a non-ATP competitive manner. 